\title{
Toxic Effects of a Chlorothiazide-Diazoxide Combination on Adipose Tissue and Kidneys of Intact Rats*
}

\author{
Harold P. Settle, JR., Willtam J. Munste, and John A. Owen, JR. \\ Division of Clinical Pharmacology, Department of Internal Medicine, and the Department of Pathology, School of \\ Medicine, University of Virginia, Charlottesville, Virginia
}

Received: July 29, 1967

Summary. In order to explore effects of chlorothiazide (CTZ) and diazoxide (DZX) on rat adipose tissue, as being possibly related to previously reported hyperglycaemia in man, intact rats fed $a d$ lib were given daily injections of CTZ $(200 \mathrm{mg} / \mathrm{kg})$, DZX ( $50 \mathrm{mg} / \mathrm{kg})$, or both for 14 days. They were then killed and their fat pads were incubated in buffer with and without insulin $(250 \mu$ units $/ \mathrm{ml})$. DZX (but not CTZ) and the combination significantly decreased baseline glucose oxidation and incorporation into lipids; response to insulin was significantly impaired by either drug alone and especially by the CTZ-DZX combination. An unexpected effect of the drug combination was severe renal disease with azotaemia and death as early as the fourth day. Histologically, the primary change seemed to be epithelial hyperplasia in the collecting tubules suggestive of the effect of potassium depletion. This in turn produced tubular obstruction with proximal dilatation and focal, acute, interstitial inflammation in both cortex and medulla.

Effets toxiques d'une association chlorothiazide-diazoxide sur le tissu adipeux et les reins de rats intacts

Résumé. Afin d'explorer les effets du chlorothiazide (CTZ) et du diazoxide (DZX) sur le tissu adipeux du rat, comme étant en relation possible avec l'hyperglycémie précédemment constatée chez l'homme, on a administré à des rats intacts, nourris ad libitum, des injections quotidiennes de CTZ $(200 \mathrm{mg} / \mathrm{kg})$, de DZX (50 mg/ $\mathrm{kg}$ ) ou des deux à la fois pendant 14 jours. Ils étaient alors tués et leur tissu adipeux était incubé dans un tampon avec et sans insuline $(\mathbf{2 5 0} \mu$ unités $/ \mathrm{ml})$. DZX (mais non CTZ) ainsi que l'association des deux substances diminuaient significativement l'oxydation basale du glucose et l'incorporation dans les lipides; la réponse à l'insuline était diminuée significativement par l'une ou l'autre drogue seule, et spécialement par l'association CTZ-DZX. L'association des deux drogues provoqua un effet inattendu, à savoir une atteinte rénale sévère avec azotémie et mort dès le quatrième jour. Histologiquement la modification primaire semble être une hyperplasie épithéliale dans les tubules collecteurs, suggérant l'effet d'une déplétion de potassium. Ceci provoqua à son tour une obstruction tubulaire avec dilatation proximale et inflammation interstitielle focale aiguë dans le cortex et la moelle.

Toxische Auswirkungen einer Chlorothiazid-Diazoxid Kombination auf Fettgewebe und Nieren von intakten Ratten

Zusammenfassung. Die Wirkung von Chlorothiazid (CTZ) und Diazoxid (DZX) auf Rattenfettgewebe wurde untersucht, insbesondere, um zu klären, ob sich zwischen diesen Effekten und der nach Verabreichung dieser Medikamente schon früher beim Menschen beschriebenen Blutzuckererhöhung Zusammenhänge finden lassen. Dabei erhielten intakte Ratten mit freiem Zugang zur Nahrung während 14 Tagen tägliche Injektionen von $200 \mathrm{mg} / \mathrm{kg} \mathrm{CTZ}, 50 \mathrm{mg} / \mathrm{kg}$ DZX oder beide Medikamente zusammen. Dann wurden die Tiere getötet und ihre Nebenhoden-Fettgewebsanhänge mit oder ohne Insulinzusatz $(250 \mu \mathrm{E} / \mathrm{ml}$ ) in Puffer inkubiert. DZX (nicht aber CTZ) und ihre Kombination führten zu einer signifikanten Senkung der Basis-Oxydation und des Einbaus von Glucose in Lipide. Das Ansprechen des Gewebes auf Insulin wurde durch jede der beiden Drogen und besonders durch die Kombination von CTZ und DZX signifikant gehemmt. Als unerwartete Folge traten bei den mit der Medikamenten-Kombination behandelten Tieren schwere Nierenerkrankungen mit Urämie und Tod, teilweise schon am 4. Tage ein. Als Primärschädigung schien, wie die histologische Untersuchung ergab, eine Epithel-Hyperplasie der Sammelröhrchen vorzuliegen, was auf die Möglichkeit hindeutet, daß es sich dabei um die Aus. wirkungen eines schweren Kalium-Mangelzustandes handeln könnte. Weiter kam es infolge dieser Hyperplasie zu einem Verschluß der Tubuli mit proximaler Erweiterung und zu akuten, abszedierenden Entzündungen im Inter. stitium von Rinde und Mark.

Key-words: Acute pyelonephritis, adipose tissue in vitro, azotaemia, chlorothiazide, diazoxide, glucose oxidation, lipid incorporation, potassium depletion.
Chlorothiazide, the prototype of the benzothiadiazine group of drugs, was synthesized in 1957 and soon proved itself a potent diuretic and anti-hypertensive agent. WrikiNs (1959) was the first to describe its tendency to produce hyperglycaemia or unmask latent diabetes mellitus. Diazoxide, synthesized in 1961, is a chlorothiazide derivative with anti-hypertensive but

* Presented in part at the Annual Meeting of the American Therapeutic Society, Chicago, Illinois, June 23, 1966. Supported by U.S.P.H.S. Grant HE 5544-04. An abstract of these results has previously appeared (SETTLE et al., 1966). only mildly saluretic properties; its clinical trials also brought reports of hyperglycaemia (DoLLERY et al., 1962), now thought to be due to direct inhibition of insulin secretion (FAJANS et al.; 1966; SELTZER and Crout, 1966).

Only three articles have reported direct effects of these agents on glucose utilization by peripheral tissues. Fiesd and Mandele (1964) found that neither chlorothiazide $(16-160 \mu \mathrm{g} / \mathrm{ml})$ nor diazoxide (30$300 \mu \mathrm{g} / \mathrm{ml}$ ) altered glucose oxidation by the rat epididymal fat pad in vitro, but intraperitoneal injections of chlorothiazide $(1 \mathrm{mg} / 100 \mathrm{~g}$ body weight daily for 14 
days) significantly reduced the effect in vitro of insulin on adipose tissue but not on diaphragm. BARNETT and WHITNEY (1966) carried out similar studies with different results: chlorothiazide $(600 \mu \mathrm{g} / \mathrm{ml})$ in vitro inhibited both the basal glucose uptake and the insulin response of rat hemidiaphragm but not of adipose tissue; diazoxide in the same concentration inhibited the basal glucose uptake of adipose tissue but not that of hemidiaphragm, and did not depress the insulin response of either tissue. The discrepancy between these effects of diazoxide may be due to dosage differences; the different chlorothiazide effects cannot be readily explained. The present studies were designed to reinvestigate the impact of these drugs on adipose tissue and to clarify, if possible, its relationship to the hyperglycaemic effect.

Some time after this study was completed, there appeared the report of $\mathrm{J}_{\text {ANSEN }}$ et al. (1967), showing that a single subcutaneous injection of diazoxide $(2-$ $20 \mathrm{mg}^{\mathrm{s}}$ per $100 \mathrm{~g}$ of body weight) acutely raised the blood sugar and impaired the incorporation into adipose tissue fatty acid of labelled glucose given by tabe to intact mice. Crystalline insulin ( 0.25 units per animal) reversed these diazoxide-induced effects, but when given alone did not increase the radioactivity in the adipose tissue despite a marked fall in blood sugar.

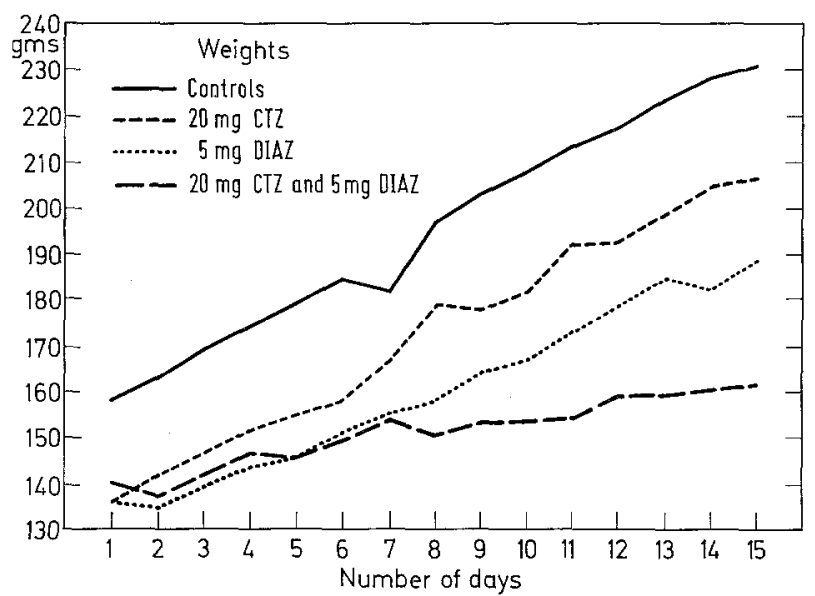

Fig. 1. Weight gains of the groups of rats on various treatments

\section{Methods}

104 male Wistar rats weighing $125-150 \mathrm{~g}$ were randomly divided into four groups assigned to receive fourteen daily i.p. injections : controls received $1.0 \mathrm{ml}$ sterile saline; another group received chlorothiazide, $20 \mathrm{mg}$ per $100 \mathrm{~g}$ of body weight; a third group received diazoxide, $5 \mathrm{mg}$ per $100 \mathrm{~g}$ of body weight; and the last group received chlorothiazide and diazoxide in the above doses, by separate injections. Chlorothiazide was obtained as commercial sodium salt, Lyovac ${ }^{\circledR}$ Diuril ${ }^{\circledR 1}$, and made into solution $(25 \mathrm{mg} / \mathrm{ml}$

\footnotetext{
1 Merck Sharp and Dohme.
}

of normal saline) immediately prior to injection. Diazoxide was obtained as Hyperstat ${ }^{\circledR}$ Solution ${ }^{2}$ $(15 \mathrm{mg} / \mathrm{ml}$ ) and injected as such. The animals were given Purina Lab Chow and water ad lib, weighed daily, and decapitated on day 15. Plasma urea and glucose were measured using the Technicon Autoanalyzer.

The epididymal fat pads were removed, and one weighed segment (ca. $200 \mathrm{mg}$ ) from each rat was incubated in a flask containing $5 \mathrm{ml}$ of Krebs bicarbonate buffer ( $\mathrm{pH} 7.4$ ), glucose $2.5 \mathrm{mg} / \mathrm{ml}$ including $2 \mu \mathrm{c}$ of glucose-1-14 $\mathrm{C}$, and crystalline beef insulin, 250 urnits $/ \mathrm{ml}$; the other segment was incubated in a

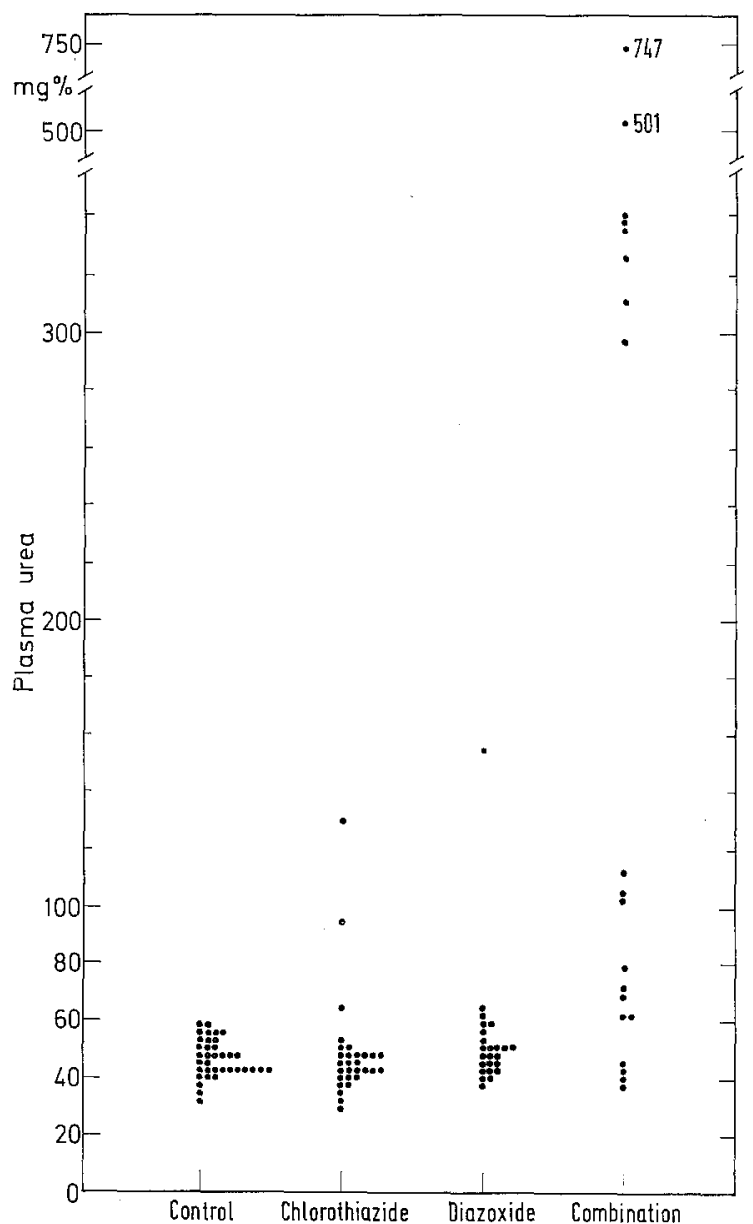

Fig. 2. Scatter diagram of terminal values of plasma urea

similar flask containing the identical medium but without insulin. The flasks were agitated for $3 \mathrm{~h}$ in a Dubnoff incubator at $37^{\circ} \mathrm{C}$. Glucose oxidation to $\mathrm{CO}_{2}$ was estimated by the method of RENord et al. (1960) and SHEPs et al. (1960), modified so that ${ }^{14} \mathrm{CO}_{2}$ was collected in Hyamine ${ }^{3}$. After incubation the lipids of the fat pad were extracted and their ${ }^{14} \mathrm{C}$ incorporation measured by the method of BARUCH and CHAIKOFE

2 Schering Corporation.

3 Rohm and Haas Company. 
(1954), modified to substitute heptane for chloroform in the lipid extraction with sodium ethylate. Each sample was counted in a Packard Tricarb counter and results expressed as $\mathrm{dpm}$ per $\mu \mathrm{g}$ of adipose tissue statistical tests such as the Student's $t$ seemed inappropriate; differences between treatment groups were analyzed using the Wilcoxon rank sums method (WILCoxoN and WILCOX, 1964).

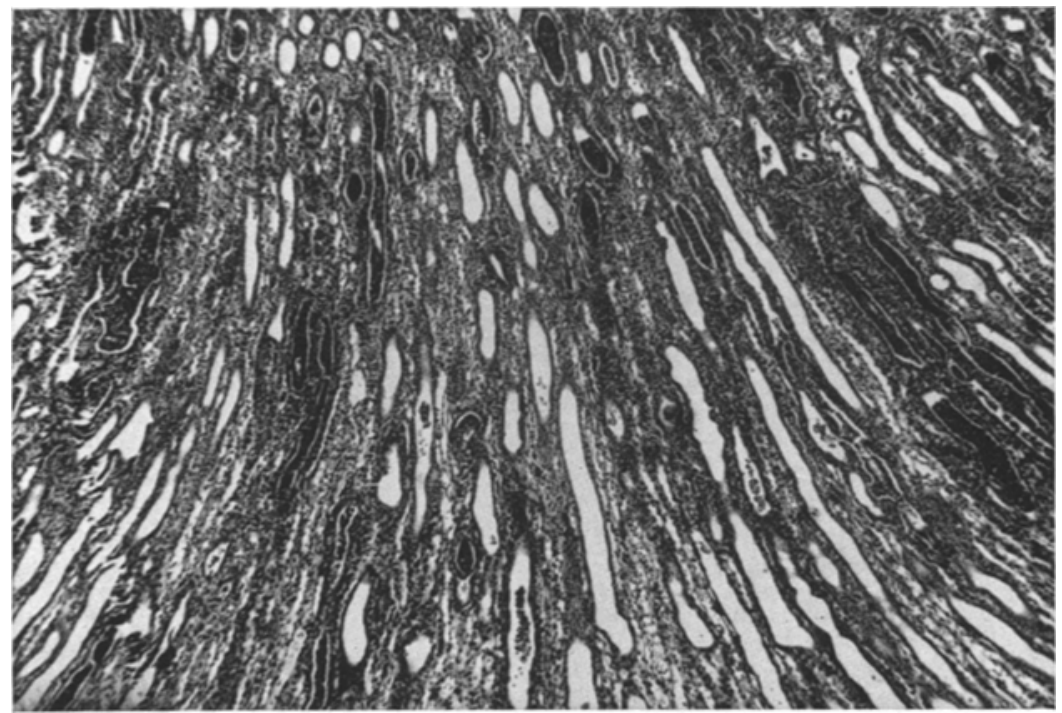

Fig. 3. Section of renal medulla. Kidney was obtained from azotaemic rat after 14 days' treatment with the combination of chlorothiazide and diazoxide. $H \& \mathbf{E}$ stain, $\times 48$

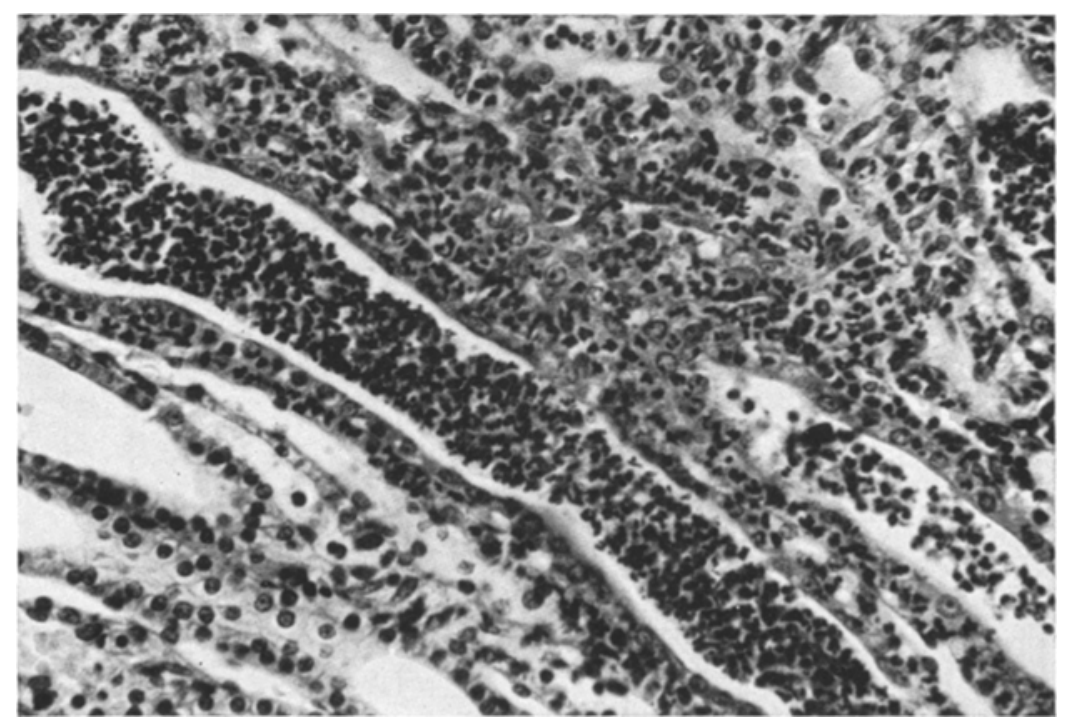

Fig. 4. Section of renal medulla, from same kidney (different area) as shown in Figure 3, demonstrating tubular plugging and inflammation in interstitium. H \& E stain, $\times \mathbf{3} 00$

nitrogen. An aliquot of each fat pad was analyzed for nitrogen by the micro-Kjeldahl method. The response to insulin was obtained by subtracting the values for the epididymal segment incubated without insulin from the values for the corresponding paired segment incubated with insulin. Because the values obtained did not follow a normal distribution curve, parametric

\section{Results}

Animals which received these large benzothiadiazine doses usually looked sick for an hour or so after each injection. As shown in Fig. 1, chlorothiazide treatment did not inhibit weight gain $(5.0 \mathrm{~g} /$ day $)$, which was essentially the same as that in the control group $(5.3 \mathrm{~g} /$ day $)$; the diazoxide-treated group gained somewhat less ( $3.8 \mathrm{~g} / \mathrm{day})$, and the combinationtreated group least of all $(1.6 \mathrm{~g} / \mathrm{day})$. This latter group suffered a $33 \%$ mortality as compared with $4-7 \%$ for the other groups.

None of the rats were hyperglycaemic when killed. But many of those treated with the combination had high values for plasma urea (Fig. 2), an unexpected finding which was the stimulus for considerable further study (SETTLE and OwEN, 1968).

Chlorothiazide treatment did not significantly alter the metabolism of glucose by adipose tissue in buffer alone. Diazoxide markedly depressed glucose oxidation by adipose tissue compared with that by adipose tissue of control and chlorothiazide-treated rats; incorporation of the label into lipid was also impaired but to an extent which was significant only in comparison with the controls. The combination of chlorothiazide and diazoxide was only slightly more inhibitory than diazoxide alone. Either drug significantly impaired the expected responses to insulin; the greatest effect occurred in animals receiving the combination treatment (Table 1).

The persistent failure to thrive, the increased mortality, and the azotaemia at time of killing prompted pathological examination of the kidneys of some rats receiving the combination treatment. There were two types of pathological changes in these kidneys. One was suggestive of potassium depletion as described in rats by OuIver et al. (1957), and consisted of hyperplasia of the epithelium of the collecting duct, and dilatation of the more proximal tubules. The other was acute pyelonephritis consisting of acute focal interstitial inflamma- 
tion, involving both cortex and medulla, with occasional small abscesses and many cellular casts of polymorphonuclear leukocytes in the collecting tubules (Fig. 2-4). These changes were first seen on the fourth day of injection.

\section{Discussion}

These rather large doses of chlorothiazide and diazoxide were used because in pilot studies smaller amounts had had but little effect on the glucose tolerance of treated rats. The parenteral route of administration was chosen to obviate the technical problems of tube-feeding.

Several factors may have influenced the metabolism of adipose tissue in these animals. None of the treated groups gained weight as rapidly as the controls, but only the group injected with the combination of drugs lagged strikingly (Fig. 1). These rats were obviously sick and probably ate little (food intake was not measured); semi-starvation undoubtedly played an important role in the altered metabolism of adipose tissue, quite independent of drug effects per se. consider the effects of the drugs themselves. Chlorothiazide treatment for two weeks produced a variable and insignificant reduction of baseline glucose meta bolism; more striking and quite significant was the impairment of the expected stimulatory effect of

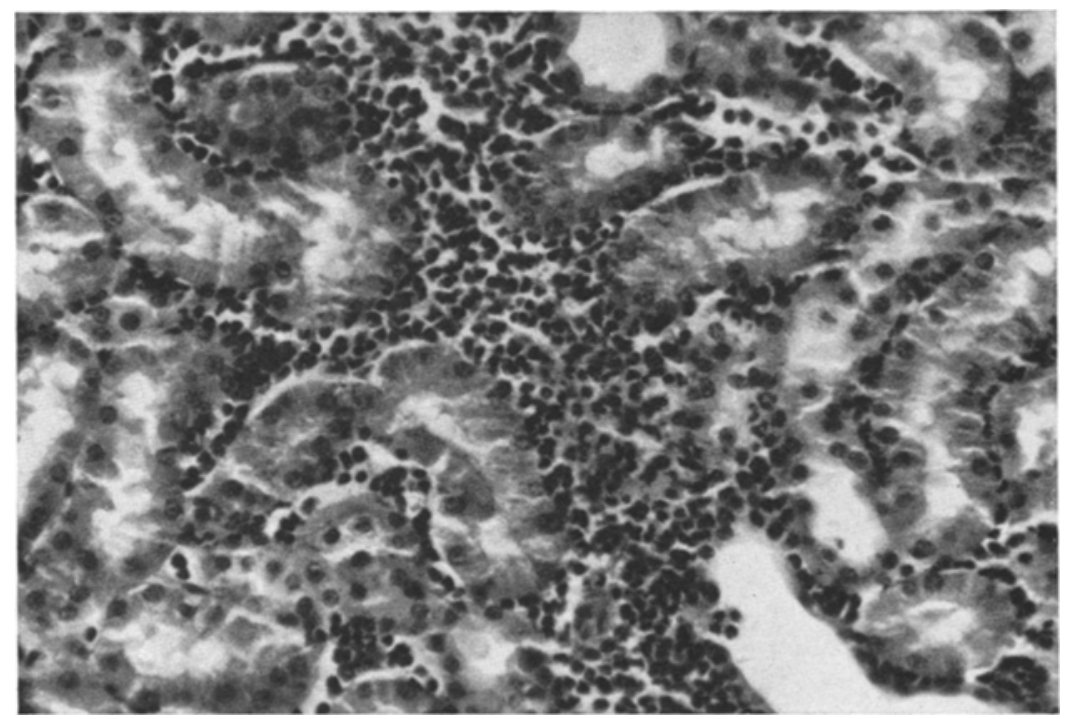

Fig. 5. Section of renal cortex. Acute inflammation in interstitium and microabscess formation. H \& E stain, $\times 300$

Table 1. Glucose-1-14C metabolism by adipose tissue

\begin{tabular}{|c|c|c|c|}
\hline \multirow{2}{*}{$\begin{array}{l}\text { Treatment } \\
\text { Group \& No. }\end{array}$} & \multicolumn{2}{|c|}{$\begin{array}{l}\text { dpm/ } / \mu \text { g adipose tissue } \mathrm{N} \text { (average and } \\
\text { range) }\end{array}$} & \multirow[t]{2}{*}{$\begin{array}{l}P \text { values for rank sums } T \text { values for treatment } \\
\text { group comparisons* }\end{array}$} \\
\hline & $\begin{array}{l}\text { Production of } \\
{ }^{14} \mathrm{CO}_{2}\end{array}$ & $\begin{array}{l}\text { Incorporation of } \\
{ }^{14} \mathrm{C} \text { into lipid }\end{array}$ & \\
\hline
\end{tabular}

A. Baseline utilization in buffer alone

\begin{tabular}{ll|l|l|l|l|l}
\hline Control & $(36)$ & $24.9(6.8-53.7)$ & $28.5(7.6-78.5)$ & Control vs. & Chlorothiazide & Diazoxide \\
Chlorothiazide & $(29)$ & $30.8(9.0-76.7)$ & $22.9(3.5-60.6)$ & N.S.; N.S. & vs. & vs. \\
Diazoxide & $(24)$ & $17.1(5.7-104.6)$ & $21.9(5.1-89.4)$ & $<0.01 ;<0.05$ & $<0.01 ;$ N.S. & \\
Combination & $(15)$ & $15.0(2.9-35.4)$ & $16.1(2.4-40.3)$ & $<0.01 ;<0.01$ & $<0.01 ;$ N.S. & N.S.; N.S. \\
\hline
\end{tabular}

B. Effect of insulin ( $250 \mu$ units $/ \mathrm{ml}$ ) in buffer ( $\Delta$ effect)

\begin{tabular}{ll|l|l|l|l|l}
\hline Control & $(36)$ & $54.8(-11.6-170.0)$ & $81.2(-32.7-330.6)$ & Control vs. & Chlorothiazide & Diazoxide \\
Chlorothiazide (29) & $17.6(-14.2-64.2)$ & $28.4(-26.7-119.7)$ & $<0.01 ;<0.01$ & vs. & vs. \\
Diazoxide & $(24)$ & $6.6(-9.5-25.7)$ & $11.3(-25.6-90.9)$ & $<0.01 ;<0.01$ & $<0.05 ;<0.01$ & \\
Combination & $(15)$ & $5.9(-1.9-18.6)$ & $12.4(-7.5-53.8)$ & $<0.01 ;<0.01$ & $<0.01 ;<0.02$ & N.S.; N.S. \\
\hline
\end{tabular}

* In each column, the first figure refers to $\mathrm{CO}_{2}$ production, the second to lipid incorporation.

Since both chlorothiazide and diazoxide solutions are alkaline (pH 9.3 and 11.2 , respectively), direct chemical damage to the epididymal fat pads may have resulted from intraperitoneal injection. This explanation seems unlikely in view of the similar findings by Jansen et al. (1967), employing only a single subcutaneous injection. Nevertheless, a possible additive effect cannot be ruled out.

With these reservations, it is now possible to insulin. Diazoxide treatment, on the other hand, produced a marked and significant lowering of both baseline and insulin-stimulated metabolism, an effect which was only minimally enhanced by the further addition of chlorothiazide. The changes in glucose oxidation closely paralleled those in incorporation of glucose carbon into lipid. The effects of the combination treatment cannot be distinguished from the systemic complications of the nephrotoxicity. 
These effects of chlorothiazide confirm the studies reported by Fiesd and MaNdeLc (1964); despite a 20 -fold increase in the dose employed, baseline glucose oxidation was not impaired, the response to insulin was blunted, and hyperglycaemia did not occur. The present findings, like those of JANSEN et al. (1967), implicate diazoxide as a much stronger inhibitor of adipose tissue metabolism than might be inferred from the studies in vitro of BARNETT and WHITNEY (1966), who found no depression of insulin response by the same dose that depressed basal uptake. This discrepancy suggests that diazoxide injected in vivo may act both directly on adipose tissue and indirectly on adipose tissue and/or insulin secretion, the latter actions perhaps mediated via adrenergic release as postulated by TABACHNICK et al. (1964). A concept of multiple sites of action is also compatible with the observed dissociation of effects on blood sugar and adipose tissue. Although acute diazoxide-induced hyperglycaemia occurs consistently (WoLFF et al., 1963; WolfF and PARMLey, 1964) and accompanies acute supression of adipose tissue (JANSEN et al., 1967), the blood sugar was normal in the present study $24 \mathrm{~h}$ after the fourteenth diazoxide injection, at a time when both glucose utilization by, and insulin effect on, adipose tissue were markedly impaired.

The effects on renal function and morphology were totally unexpected and unprecedented, although TABACHNICK et al. (1964) had earlier reported a modest azotaemic effect of diazoxide alone in intact mice and dogs. The present experiments revealed little nephrotoxicity except with the combination treatment, which caused striking growth impairment, mortality and renal pathology. The severity of this systemic illness, if it is consistently demonstrable, will always obscure any long-term effects of the drug combination per se on the metabolism of adipose tissue. Further experiments to be reported will attempt to elucidate this phenomenon.

Acknowledgments. We wish to thank Professor D.R.H. GoURLEY, Department of Pharmacology, for his advice and encouragement and Dr. Eugene Foster for his help in interpreting the pathological changes. Mr. WILLIAM J. KAGEY contributed greatly to this experiment by his careful work in earlier pilot studies.

We also wish to thank Dr. Elmer AlPert of Merck Sharp and Dohme, and Dr. I. I. A. TABACHNICK of the Schering Corporation, for generous and unfailing supplies of chlorothiazide and diazoxide, respectively.

\section{References}

BARnetr, C.A., and J.E. WHTTNEY: The effect of diazoxide and chlorothiazide on glucose uptake in vitro. Metabolism 15, 88-93 (1966).
Baruch, H., and I. L. Chaikofr : A simplified method for determination of lipide-C $\mathrm{C}^{\mathbf{1 4}}$ in liver. Proc. Soc. exp. Biol. 86, $97-99$ (1954).

Dollery, C.T., B.L. Pentecost, and N.A. Saman: Drug-induced diabetes. Lancet 1962 II, 735-737.

Fajans, S.S., J.C. Floyd, Jr., R.F. Knopy, J. RuLl, E.M. Guntsche, and J.W. Conn: Benzothiadiazine suppression of insulin release from normal and abnormal islet tissue in man. J. clin. Invest. 45, $481-492$ (1966).

Freld, J.B., and S. Mandeli: Effects of thiazides on glucose uptake and oxidation of rat muscle and adipose tissue. Metabolism 13, 959-963 (1964).

JANSEN, G.R., C.F. HuTChison, and M.S. ZANETTI: Effect of diazoxide on glucose U-C-14 utilization in mice. Diabetes 16, $777-783(1967)$.

Oliver, J., M. MaODowell, L.G. Welt, M. A. Hollidday, W. Hollander, Jr., R. W. Winters, T.F. Williams, and W.E. SEgAR: The renal lesions of electrolyte imbalance. I. The structural alterations in potassium. depleted rats. J. exp. Med. 106, 563-574 (1957).

Renold, A. E., D.B. Martin, Y.M. Dagenats, J. Steinke, R.J. Nickerson, and M.C. Sheps: Measurement of small quantities of insulin-like activity using rat adipose tissue. I. A proposed procedure. J. clin. Invest. 39, $1487-1498(1960)$

Seltzer, H.S., and J.R. Crout: Effects of different benzothiadiazines and catecholamines on insulin secretion. Program of the 48 th meeting of the Endocrine Society, Chicago, Illinois, June 22, 1966.

Settle, H.P., Jr., R.T. KILey, W.J. Munsie, and J.A. OWEN, Jr.: Chlorothiazide-diazoxide hyperglycemia and nephrotoxicity in the intact rat. Clin. Res. Proc. 14, $78(1966)$.

-, and J.A. OwEN, Jr.: Effects of chlorothiazide, diazoxide, and their combination in vivo on LDH isoenzymes of rat kidney. In preparation, 1968.

ShePs, M.C., R.J. Nickersor, Y.M. Dagenats, J. Steinke, D.B. Martin, and A.E. Renold: Measurement of small quantities of insulin-like activity using rat adipose tissue. II. Evaluation of performance. J. clin. Invest. 39, 1499-1510 (1960).

Tabachnick, I.I.A., A. Gulberikian, and F. Seidman: The effect of a benzothiadiazine, diazoxide, on carbohydrate metabolism. Diabetes 13, $408-418$ (1964).

WILCoxoN, F., and R.A. WILCOX: Some rapid approximate statistical procedures, p. 7. Pearl River, N.Y.: The American Cyanamid Co. 1964.

WiLkins, R.W.: New drugs for the treatment of hypertension. Ann. intern. Med. 50, 1-10 (1959).

Wolify, F.W., R.G. Langdon, B.H. RuebneR, G. Hollander, and R.D. SkogLUND: A new form of experimental diabetes. Diabetes 12, 335-338 (1963).

- , and W.W. PARMLEY: Further observations concerning the hyperglycemic activity of the benzothiadiazines. Diabetes 13, 115-124 (1964).

Dr. JoHr A. OWEN, Jr., Department of Internal Medicine University of Virginia School of Medicine

Charlottesville, Virginia, U.S.A. 